\title{
Activation of Helicobacter Pylori Causes Either Autoimmune Thyroid Diseases or Carcinogenesis in the Digestive Tract
}

\section{J. ASTL ${ }^{1,2}$, I. ŠTERZL $^{3}$}

${ }^{1}$ Department of Otorhinolaryngology, Third Faculty of Medicine, Charles University and Military Faculty Hospital, Prague, Czech Republic, ${ }^{2}$ Department of Otorhinolaryngology and Head and Neck Surgery, First Faculty of Medicine, Charles University, University Hospital Motol, Prague, Czech Republic, ${ }^{3}$ Department of Immunoendocrinology, Institute of Endocrinology, Prague, Czech Republic

Received June 26, 2015

Accepted August 24, 2015

\section{Summary}

Helicobacter pylori has been implicated in stimulation of immune system, development of autoimmune endocrinopathies as autoimmune thyroiditis (AT) and on other hand induction of immunosupresion activates gastric and extra-gastric diseases such as gastric ulcer or cancer. It causes persistent lifelong infection despite local and systemic immune response. Our results indicate that Helicobacter pylori might cause inhibition of the specific cellular immune response in Helicobacter pyloriinfected patients with or without autoimmune diseases such as AT. We cannot also declare the carcinogenic effect in oropharynx. However the association of any infection agents and cancerogenesis exists. The adherence of Helicobacter pylori expression and enlargement of benign lymphatic tissue and the high incidence of the DNA of Helicobacter pylori in laryngopharyngeal and oropharyngeal cancer is reality. LTT appears to be a good tool for detection of immune memory cellular response in patients with Helicobacter pylori infection and AT. All these complications of Helicobacter pylori infection can be abrogated by successful eradication of Helicobacter pylori.

\section{Key words}

Helicobacter pylori - Autoimmune thyroiditis - MELISA • CagA gene $\bullet$ Tonsillar tissue $\bullet$ Oropharynx $\bullet$ Mutagen $\bullet$ Cancer

\section{Corresponding author}

I. Šterzl, Department of Immunoendocrinology, Institute of Endocrinology, Národní 8, Prague 1, CZ-11694, Czech Republic. E-mail: isterzl@endo.cz

\section{Introduction}

Helicobacter pylori is gram-negative, microaerophilic, spiral, and cosmopolitan bacterium. It has been associated with common gastric diseases, especially with chronic and active gastritis and peptic ulcer disease and, in some cases, also with gastric cancer. The bacterium was first described by Marshall and Warren in 1984. The public health importance of the $H$. pylori discovery was recognized in 2005 by acknowledgement of the Nobel Prize. The prevalence in Central and Eastern Europe is estimated from 60 to $95 \%$ (Covacci et al. 1999). Clinical manifestation appears in only 10-15\% of infected individuals. Although much information on its epidemiology is known, the mechanism of the transmission remains unclear. There are three routes of transmission: oral-oral, fecal-oral and gastric-oral (Nomura et al. 1991). The stomach was supposed to be the only reservoir of infection in humans.

The most important virulence factors associated with gastric pathogenesis are CagA protein (cytotoxin) and VacA (vacuolating cytotoxin A). Genes encoding virulence factors of $H$. pylori are grouped in the cagPAI (Pathogenicity Island) region and some of them encode a type IV bacterial secretion apparatus. This apparatus translocates CagA into host cells in gastric mucosa. The CagA protein stimulates cell signaling through the interaction with several host proteins. This interaction leads to an increased release of cytokines, especially 
interleukin 1, interleukin 6, interleukin 10 and tumor necrosis factor $\alpha$ and regulatory molecule production (Parsonnet et al. 1991, 1994).

VacA is also an important virulence factor as it causes vacuolation. There are differences among $H$. pylori strains in the structure of VacA. Two types of signal regions are known $-\mathrm{s} 1$ and $\mathrm{s} 2$. There are also two types of mid-regions known $-\mathrm{m} 1$ and $\mathrm{m} 2$. Strains bearing the VacA s1m1 gene showed higher degrees of gastric colonization (Parsonnet et al. 1991, RadoszKomoniewska et al. 2005, Salama et al. 2013).

\section{Immunomodulation and autoimmunity}

The chronic inflammation can lead to autoimmune immunopathological reactivity. The most important mechanism by which $H$. pylori induces gastric autoimmunity is molecular mimicry, cross-reaction between antigens expressed both on $H$. pylori and on gastric parietal cells in proton pump, $\mathrm{H}^{+}, \mathrm{K}^{+}$-ATPase (Bergman et al. 2005, D'Elios et al. 2004). Besides gastric disorders, the $H$. pylori etiology is discussed in connection with the development of different extragastric diseases such as vascular, skin and autoimmune diseases such as autoimmune thyroiditis (De Koster et al. 2000, Martin-de-Argila et al. 1995, Nilsson et al. 2005, Realdi et al. 1999, Solnick et al. 2006, Tsang and Lam 1999).

Immunological changes caused by $H$. pylori in the stomach mucosa were explained recently (Tummala et al. 2004). H. pylori induces local and systemic immune response involving both innate and adaptive immunity. Despite of a cellular and humoral immune response, the host organism is often not able to eliminate the $H$. pylori infection. The inability of the host to clear the infection and pronounced inflammatory response leads to persistent infection and tissue damage. During the $H$. pylori infection, the lymphocytes are predominantly differentiated to Th1 subtypes that are associated with cytotoxic reaction responsible for damage of gastric mucosa rather than elimination of the infection (PortalCelhay and Perez-Perez 2006, Robinson et al. 2007, Suarez et al. 2006, Velin and Michetti 2006).

The inability to eliminate the infection may be due to bacterial virulence determinants and immuneevasive strategies as well as an inappropriate host immune response. H. pylori LPS, compared with other gram-negative bacteria, has been described as a poor TLR activator of the innate immune response and $H$. pylori flagellin as well (Bliss et al. 1998, Gewirtz et al. 2004, Muotiala et al. 1992). The pathogen-recognition molecule Nod1-mediated interaction appears to be more important for induction of the inflammatory response than those mediated by TLR-4 and TLR-5, especially in CagA positive H. pylori strains (O'Keeffe and Moran 2008, Viala et al. 2004). Part of $H$. pylori strains posseses cytotoxin-associated gene pathogenicity island (cag-PAI) encoding a type IV bacterial secretion system through which a CagA protein, the most important $H$. pylori virulence factor, is translocated into gastric epithelial cells to induce pro-inflammatory cytokine IL-8 (Blaser and Atherton 2004, Crabtree et al. 1994).

H. pylori has several mechanisms to elude host defences (Portal-Celhay and Perez-Perez 2006). It is able to survive the acidic gastric environment by producing the enzyme urease, which metabolizes urea to carbon dioxide and ammonia to buffer the gastric acid. H. pylori moves across gastric mucus and can adhere to epithelial cells using a variety of adhesin-like proteins (Sachs et al. 2003). Once adhered to epithelial cells, H. pylori induces a strong immune system response (Crabtree et al. 1994). This response does not lead to elimination of the bacterium, but causes development of chronic inflammation. $H$. pylori is not eradicated unless an infected individual is treated with a combination of antibiotics (Portal-Celhay and Perez-Perez 2006). Chemical products of $H$. pylori attract cells of the immune system into lamina propria (Blanchard et al. 2004). It was shown that $H$. pylori can induce the maturation and activation of monocyte-derived dendritic cells. This activity is mediated by TLRs (Toll-like receptors) expressed on antigen presenting cells and leads to promotion of NK and Th1 effector responses (PortalCelhay and Perez-Perez 2006). IFN- $\gamma$ producing Th1 polarized $\mathrm{T}$ cells and activated NK cells have been suggested to play an important role for development of severe pathologies (Hafsi et al. 2004).

Systemic immune and inflammatory responses to H. pylori were described extensively related to extragastrointestinal system diseases. Recent studies have identified a potential relationship between H.pylori infection and the pathogenesis of cardiovascular, neurological, dermatological, immunological, hematological, hepatobiliary, ophthalmological and gynecological diseases, and organ specific autoimmune diseases (autoimmune thyropathies) (Hasni 2012), as well as diabetes mellitus (De Koster et al. 2000, Martin-deArgila et al. 1995, Nilsson et al. 2005, Realdi et al. 1999, 
Solnick et al. 2006, Tsang and Lam 1999), systemic autoimmune diseases - Sjögren's syndrome (Figura et al. 2010). A role of H. pylori in the development of lower respiratory disease has also been suggested, but a pathophysiological association has not been proven.

Our study in Czech Republic demonstrated the occurrence of $H$. pylori in the same rates as in other developed countries with a slightly lower occurrence of seropositive anti-TPO and anti-Tg, and confirmed the link of $H$. pylori infection to the gastric parietal autoimmunity (Sterzl et al. 2008) and autoimmune thyroiditis (Hybenova et al. 2010b).

In patients with autoimmune thyropathies, mainly with the atrophic form of autoimmune thyroiditis but also in patients with Graves' thyrotoxicosis and Hashimoto's thyroiditis an increased prevalence of $H$. pylori was described. That finding is supported by a finding of elevated levels of IgG anti-H. pylori antibodies and by the breath test results. In patients suffering from autoimmune thyroiditis and infection by $H$. pylori also abnormalities in the secreting function of the stomach were found (elevated levels of gastrin, pepsinogen I and pepsinogen II) (Yanaoka et al. 2009).

Recently Figura et al. (1999) described that monoclonal antibodies against Cag antigen of $H$. pylori react with the follicular cells of the thyroid. H. pylori having the Cag pathogenicity island is a carrier of a gene coding the endogenous peroxidase. According to this, CagA positive H. pylori infection increases the risk of the development of autoimmune thyroiditis (Figura et al. 1999).

In our study, we have determined specific cellular immune response to $H$. pylori antigens in two groups of $H$. pylori infected patients using modified lymphocyte transformation test, LTT-MELISA, before and after eradication therapy in comparison with healthy controls. In comparison with healthy $H$. pylori negative controls, immune reactivity to majority of $H$. pylori antigens was significantly lower in group before eradication therapy. In this group, significant increase of immune reactivity was observed in certain $H$. pylori antigens after successful eradication. Our results indicate that $H$. pylori might cause inhibition of the specific cellular immune response in $H$. pylori infected patients with or without autoimmune diseases such as AT, which can be abrogated by successful eradication of H. pylori. LTT appears to be a good tool for detection of immune memory cellular response in patients with $H$. pylori infection (Hybenova et al. 2010a).
H. pylori infection in gastric mucosa is associated with the production of both proinflammatory and immunomodulatory cytokines. Changes in secretion of IL-8, IL-1beta, IL-6, TNF-alpha, TGF-beta were described (Stromberg et al. 2003). These cytokines are produced by both the immune system and epithelial cells. The response of host cells is dependent on production of H. pylori virulence factors (Blanchard et al. 2004). The most important virulence factors, which are associated with gastric diseases, are CagA (cytotoxic associated gene A) and VacA (vacuolating cytotoxin A).

\section{Carcinogenesis and immunosuppression}

Long lasting inflammatory response may cause an accumulation of genetic defects in epithelial cells, altered cell growth regulation resulting in carcinogenesis. H. pylori has been classified as class I carcinogen by the World Health Organization (Logan 1994). About $1 \%$ H. pylori infected individuals develop Bystric adenocarcinoma and in a few percent, infection leads to MALT lymphoma. It was also described that $H$. pylori could act in pathogenesis of oropharyngeal carcinogenesis (Akbayir et al. 2005, Kizilay et al. 2006, Nurgalieva et al. 2005, Pavlik et al. 2007). However, the exact mechanism of carcinogenesis has not yet been fully understood. The immunosuppression can be mediated by H. pylori VacA or induction of $\mathrm{T}$ regulatory cells (Gebert et al. 2004, Lundgren et al. 2003). H. pylori CagA has been suggested as a direct mutagen (Hatakeyama 2009). There are three supposed ways of $H$. pylori carcinogenic action: 1) H.pylori could act as direct mutagen. Interaction of intracellular signaling molecules and $H$. pylori CagA may predispose cells to accumulate multiple genetic and epigenetic changes that promote multistep carcinogenesis (Hatakeyama and Brzozowski 2006). 2) H.pylori produced VacA can cause immunosuppression by blocking proliferation of $\mathrm{T}$ cells (Boncristiano et al. 2003). 3) H. pylori can induce cell proliferation by increasing levels of several cytokines and regulatory molecules, which are involved in tumor formation and cell transformation (Konturek et al. 1997). Current information about regulation mechanism of epithelial tissue by cytokines and regulatory molecules focus an interest mainly on Epithelial Growth Factor (EGF), Transforming Growth Factor (TGF) and NO synthases (Yanaoka et al. 2009, Gebert et al. 2004, Hasni 2012, Schiemann et al. 2002).

H. pylori and the $\operatorname{Cag} A$ gene have frequently 
been detected in asthma patients (Malfertheiner et al. 2011, Wang et al. 2013), extragastric disease (Banic et al. 2012, Figura et al. 2010, Lukes et al. 2013, Pellicano et al. 2009) and in nasal polyp specimens and the inflamed mucosa of the paranasal sinus in patients with chronic rhinosinusitis (Dinis et al. 2005, Kaviani et al. 2009, Morinaka et al. 2003, Ozyurt et al. 2009). H. pylori might play a positive role in chronic rhinosinusitis. The prevalence of sinonasal $H$. pylori is higher in patients with than without chronic rhinosinusitis. Recent functional endoscopic sinus surgery for patients with chronic rhinosinusitis revealed that postoperative endoscopic scores improved significantly more among patients with chronic rhinosinusitis and $H$. pylori sinonasal colonization.

Several studies have detected $H$. pylori in adenoids and considered that the adenoids might serve as an ecological niche and as an extra-gastric reservoir for H. pylori. However, contradictory opinions have also been expressed. An analysis of 78 pediatric patients concluded that adenoid inflammation and enlargement are probably not due to ongoing $H$. pylori infection. In addition, some authors reported that $H$. pylori has a limited (if any) role in the process of adenoid disease (Kraus et al. 2014). The pathophysiological role of H. pylori in adenoid tissue remains controversial and a definitive relationship between $H$. pylori and adenoid disease has not been established.

Multivariate regression analyses in two case control studies identified $H$. pylori infection as an independent risk factor for laryngohypopharyngeal carcinoma (Lukes et al. 2013, Rezaii et al. 2008). A recent study of a large patient cohort associated immunohistochemically detected $H$. pylori expression in oral squamous cell carcinoma with reduced disease-free survival.

In contrast, others have not found $H$. pylori in head and neck cancers or in laryngeal carcinoma samples (Lukes et al. 2013, Nartova et al. 2014, Pavlik et al. 2007). PCR, culture and immunohistochemical methods did not detect $H$. pylori in head and neck tumor tissues from 31 patients, even though 21 of them carried antiH. pylori antibodies. A statistically significant difference in the incidence of $H$. pylori seropositivity between patients with head and neck cancer and controls has not yet been reported and others have shown that $H$. pylori infection either protects against or promotes laryngopharyngeal carcinoma.

The presence of $H$. pylori in head and neck tumor tissues and/or the stomach of patients with head and neck malignancies might be widespread; however, more information is required about $H$. pylori activities in patients with head and neck carcinogenesis.

\section{Helicobacter pylori: nucleic acid detection and genotyping}

H. pylori genetic analysis was based on primers and hybridization probes designed by van Doorn (2001). Three real-time PCR assays had been developed in cooperation with TIB - Molbiol GmbH, Berlin, Germany for: the $\operatorname{Cag} A$ gene, middle region of the $V a c A$ gene and the last for the $V a c A$ gene signal region. In order to confirm $H$. pylori infection in patients, serological analysis was performed. Serum samples were tested by quantitative commercial ELISA tests (EIA Helicobacter pylori, Test-Line, Czech Republic) on IgG, IgA and IgM antibodies. For specific anti-CagA protein antibodies detection, the commercial test Helicobacter p120 (CagA) ELISA TestLine was used.

\section{Discussion}

In recent years, many authors have described $H$. pylori as a well-known gastric pathogen, but many of them also described the presence of $H$. pylori in other human body areas such as dental plaque, saliva tonsillar and adenoid tissue (Katra et al. 2014, Kraus et al. 2014, Nartova et al. 2014). Several studies have shown inhibitory effects of another important $H$. pylori virulence factor, vacuolating toxin VacA on the T cell's proliferation (Boncristiano et al. 2003, Gebert et al. 2004, Molinari et al. 1998, Sundrud et al. 2004). H. pylori can induce $H$. pylori-specific regulatory $\mathrm{T}$ cells that actively suppress $\mathrm{T}$-cell response. The elimination of regulatory $\mathrm{T}$ cells led to restoration of the proliferative response to H. pylori (Kandulski et al. 2008, Lundgren et al. 2003). Das et al. (2006) presented that expression of the costimulatory molecule B7-H1 by gastric epithelial cells is higher in H. pylori infected, and this molecule can interact with mucosal T-cells resulting in suppression of T-cell activity.

Another studies on $H$. pylori immunity indicated that infection might induce $\mathrm{T}$ cell hyporesponsiveness. Both peripheral blood lymphocytes and gastric lymphocytes from $H$. pylori positive patients were shown to respond to in vitro stimulation by $H$. pylori antigens with low cytokine secretion and proliferation relative to 
H. pylori negative controls (Birkholz et al. 1993, Fan et al. 1994, Karttunen 1991, Knipp et al. 1993, Malfitano et al. 2006, Windle et al. 2005). Chmiela et al. (1996a,b) demonstrated that activation or immunosuppression can depend on the concentration of $H$. pylori and its products. In other study, inhibition of lymphocyte proliferative response to $H$. pylori by plastic adherent cells was described (Uyub and Anuar 2001).

We observed higher stimulation after autologous than heterologous $H$. pylori in proliferation response of peripheral blood mononuclear cells (PBMC). It is in contrast with other study, where proliferative response of PBMC was significantly lower after autologous than after heterologous stimulation. However, there was no significant difference when $\mathrm{T}$ cell activation markers were observed (Jakob et al. 2001).

For better characterization of immune response to $H$. pylori, we have also determined CagA/VacA status of $H$. pylori infection in patients based on serological examination and genotyping of $H$. pylori strains isolated from patients. CagA protein has been described as a antigen with high pro-inflammatory potential (Blaser and Atherton 2004, Crabtree et al. 1994). In CagA positive $H$. pylori infected patients, we detected higher immune reactivity in comparison with CagA negative patients. CagA protein is main virulence factor of $H$. pylori so probably strong immune response maybe induced in order to eliminate the invader harming significantly the host.

Although some studies demonstrated relevance of H. pylori infection in AT (Bertalot et al. 2004, de Luis et al. 1998), we did not observe differences between immune cellular reactivity in $H$. pylori infected patients with or without AT. In agreement with other study (Figura et al. 1999), we found higher prevalence of anti-CagA antibodies in patients with AT. These data indicate that $H$. pylori might cause inhibition of the specific cellular immune response in $H$. pylori infected patients with or without autoimmune diseases such as AT. This immunosuppression can be reversed by successful eradication of $H$. pylori. LTT appears to be a good tool for detection of immune memory cellular response rather than a diagnostic tool of $H$. pylori infection. Our results give a strong support to eradication therapy of $H$. pylori in general where eradication could lead to restitution of cell immune response.

The oral cavity, in particular, tonsillar tissue, is now considered to be a possible extragastric reservoir of H. pylori infection (DiBaise et al. 2002, Katra et al. 2014,
Kim et al. 2007). Culture achieves 80-90 \% sensitivity, but from the oropharynx area, it has not had such success. Immunohistochemistry was used in several studies (Sezen et al. 2013, Wibawa et al. 2011). PCR assay is to date considered the most appropriate method for detection of oropharyngeal $H$. pylori. This method was reported $100 \%$ sensitivity and specificity of detection (Skinner et al. 2001). In contrast, Hussey et al. (2011) denied previous results of studies that had used PCR method for $H$. pylori detection in tonsillar tissue. In contrast to our study, Di Bonaventura et al. (2000, 2001) did not describe tonsillar tissue like an extragastric reservoir of $H$. pylori. They detected no positive samples by culture and immunohistochemistry. In their study, there were also detected no positive tonsillar samples by PCR. In accordance with our study $H$. pylori was detected in $64 \%$ of adenoid and tonsillar tissue specimens using PCR (16S rRNA gene). Based on comparison of our results and the results of other studies, we can conclude that oropharyngeal lymphatic tissue is an extragastric reservoir of $H$. pylori. Our results support the high sensitivity and specificity of the real-time PCR technique.

The seronegativity in some patients does not exclude the presence of $H$. pylori in tonsillar tissue where it is detectable by the real-time PCR method. Our results support the hypothesis that $H$. pylori plays a role in the pathogenesis of chronic tonsillitis because of the high presence of genotype VacA s1m1 (37.5\%). Another interesting fact is that the majority of CagA-negative genotypes isolated from tonsillar tissue (55 out of $72-76.39 \%$ ) leads to idea that the main virulence factor in gastric infections CagA may not be of such importance in infections of the tonsils.

Long-term colonization of tonsillar tissue by $H$. pylori lacking CagA protein may lead to development of chronic inflammation and alteration of immune system mechanisms. There are few studies investigating the presence of $H$. pylori in patients with sleep apnoea syndrome (SAS). Nartova et al. (2014) found that the seroprevalence of $H$. pylori in patients with SAS was $75.5 \%$, so they concluded that $H$. pylori may be associated with SAS. Oral cavity (saliva and dental plaque) is now considered a possible extragastric reservoir of $H$. pylori.

The published works dealing with oropharyngeal and nasopharyngeal detection of $H$. pylori infection have yielded contradictory results. Pharyngeal detection of $H$. pylori was reported in the range of $0-90 \%$. Regarding that the various authors used different 
methods of detection, it is not possible to reach valuable conclusions. Frequently used tests like CLO test and RUT appears to be inappropriate methods for diagnosis of pharyngeal $H$. pylori. The presence of other ureaseproducing bacterial strains in the pharynx can lead to false positive results.

Culture has proved to be very difficult and not very resistant to external influences, which may even prevent a successful detection. Molecular diagnostics (PCR) can be regarded as a method with sufficient sensitivity and specificity. Results achieved by these methods demonstrated the presence of $H$. pylori in the lymphoid tissue of oropharynx and nasopharynx. PCR method allows not only detect the presence of $H$. pylori infection, but also genotyping of strains within the tissue. The fact remains that the PCR methods allow determine the presence of bacterial DNA but cannot determine whether the DNA comes from live or dead bacteria. Results of culture despite the very low numbers of positive results indicate the possible presence of viable bacteria capable of reproduction. High susceptibility of H. pylori in adverse effects during transport of specimens or during handling in the laboratory can explain low numbers of positive results of culture. Also, a frequent colonization of oropharyngeal tissue by other bacterial species can have a significant influence on the failure of the culture of H. pylori.

The assumption that the oropharyngeal H. pylori infection may contribute to oropharyngeal carcinogenesis as a direct mutagen was not confirmed yet. An analogous situation, however, occurs in the stomach, where prevalence of $H$. pylori infection among the population is reported between $40-80 \%$, serious stomach problems such as gastroduodenal ulcer disease or gastric cancer has only $10-15 \%$ of infected. Virulence of $H$. pylori strains varies according to the production of toxins. This production is due to the presence of virulence factor genes. Most important are the $\mathrm{Cag} A$ gene and $\mathrm{VacA}$ gene. The main carcinogenic effect of $H$. pylori is associated with the presence of $C a g A$ gene and $\mathrm{s} 1 / \mathrm{m} 1$ combination of alleles of $\mathrm{VacA}$ gene. Recent studies indicate that $\mathrm{H}$. pylori may exist in the oropharynx independently to the gastric infection. Comparison of genotypes of $\mathrm{H}$. pylori in the oral cavity, oropharynx, and stomach showed that an individual can host more than one strain of H. pylori in various locations. Differences were found in the presence of $\operatorname{CagA}$ gene and in the structure of $V a c A$ gene. The findings of $H$. pylori in the oral cavity and oropharynx without demonstrable specific anti-H. pylori antibodies in serum are remarkable. This could be explained by an early detection of $H$. pylori presence after primary infection, when the antibody response has not started yet. Next, the possibility that $H$. pylori could colonize the oral cavity and the oropharynx without inducing the host immune response must be considered. Another possible explanation is the presence of $H$. pylori coccoid forms. These are viable forms of bacteria that cannot be cultivated by conventional microbiological techniques and are characterized by a reduced virulence.

The question of transmission of H. pylori has not been satisfactorily resolved yet. If we consider the oraloral or fecal-oral route as a way of transmission, we can assume finding of the same H.pylori strains in the oropharynx and stomach in the same individual. The findings of different genotypes in both locations still lack an accurate explanation. Inoculation of mixtures of $H$. pylori strains and consequently their different settlements in the different areas according to sensitivity of the strains could be one of the possible explanations. It can be assumed that the area of the oropharynx is less favorable for $H$. pylori, and can only be colonized by more resistant strains. One of the negative factors for growth and reproduction of H.pylori is the presence of other bacterial strains that were able to stop the growth of $H$. pylori during in vitro experiments. A variety of bacterial colonization in the oral cavity and oropharynx can be assumed.

Epidemiological data on the prevalence of $H$. pylori infection published in the literature are often based on serological detection of specific anti- $H$. pylori antibodies. The prevalence of infection is reported $40-80 \%$. The presence of anti-H. pylori antibodies was given in relation only to gastric infection. The newly obtained data prove the possibility of the presence of $H$. pylori infection in other locations independently to the gastric infection. This should be considered in future epidemiological studies.

Not only antibodies should be evaluated but also identification of the exact location of the infection must be done. In the future it would be appropriate to focus attention on local effects of $H$. pylori in oropharyngeal lymphoid tissue. Changes in the expression of some cytokines caused by $H$. pylori, which were described in the gastric mucosa, can be expected in the oropharyngeal tissue. Another study focused on oropharyngeal $H$. pylori genotyping should be done. In the case that high virulent H. pylori strains can survive in oropharyngeal tissue, translocation of toxins into the oropharyngeal mucosa 
cells with subsequent cytokine response can be expected. Nevertheless this assumption has not been confirmed nor refuted yet.

In contrast to Unal et al. (2006) and Ye et al. (2009), we used the DNA detection and genotype analysis for $H$. pylori presence in oropharynx. In our study, we verified the presence of $H$. pylori directly in tonsillar tissue in patients with SAS. Our detection of $H$. pylori DNA in 24 of total 29 samples $(82.76 \%$ ), out of which $79.17 \%$ were CagA negative, support the hypothesis that $H$. pylori plays a role in pathogenesis of SAS. Our results on $H$. pylori DNA detection and Helicobacter seropositivity show $26.32 \%$ discrepancy, slightly in favor of real-time PCR (15.79\% compared to $10.53 \%$ ). This shows that absence of seropositivity does not mean absence of $H$. pylori infection, while presence of IgG may be anamnestic.

In conclusion, our study supports the possible role of $H$. pylori in chronic tonsillitis and SAS. Therefore, eradication of $H$. pylori infection, even if it concerns CagA negative genotypes, may prevent future oropharyngeal pathology.

Statistical analysis on comparison of $H$. pylori infection in the groups of chronic tonsillitis and SAS using $\chi^{2}$ test showed that the H. pylori presence in tonsillar tissue does not depend on the type of oropharyngeal disease $(p=0.756)$.

Oropharyngeal tonsillar tissue is an extragastric reservoir of $H$. pylori infection. The mechanism of etiological effect is still unclear.

\section{Conclusions}

The H. pylori is an infection agents with multivariate action in the tissues. In patients with autoimmune thyropathies, mainly with the atrophic form of autoimmune thyroiditis but also in patients with
Graves' thyrotoxicosis and Hashimoto's thyroiditis, an increased prevalence of $H$. pylori was described. The presence of DNA in oropharyngeal area showed the potential of Helicobacter influence to local immunity. We cannot declare the carcinogenic effect in oropharynx. But the association of any infection agents and cancerogenesis exist. The adherence of $H$. pylori expression and enlargement of benign lymphatic tissue and the high incidence of the DNA of $H$. pylori in laryngopharyngeal a oropharyngeal cancer is reality. We suggest more studies about the association of different genotypes and his influence in local immunity. The main hypothesis is: Some infection agents modified local immunity in oropharyngeal region and "open" the door to the neoplasias and cancers. This agents modified, (depressed) the local immunity. The infection agents $(H$. pylori) start the Th1 and Th2 answer with overproduction of initiators of blocker of apoptosis, the modification of tyrosine kinase signal pathway. More questions and little bit answers yet.

\section{Conflict of Interest}

There is no conflict of interest.

\section{Acknowledgements}

This work was supported by project of Ministry of Defense MO 1012 and grant NT11523 of the Internal Grant Agency of the Ministry of Health of the Czech Republic.

\footnotetext{
Abbreviations

CagA, cytotoxin associated gene A product (antigen); VacA, vacuolating toxin A; AT, autoimmune thyroiditis; TPO, thyroid peroxidase; Tg, thyroglobulin; LTT, lymphocyte transformation test; MELISA, memory lymphocyte immunostimulation assay; TLR, Toll-like receptor.
}

\section{References}

AKBAYIR N, BASAK T, SEVEN H, SUNGUN A, ERDEM L: Investigation of Helicobacter pylori colonization in laryngeal neoplasia. Eur Arch Otorhinolaryngol 262: 170-172, 2005.

BANIC M, FRANCESCHI F, BABIC Z, GASBARRINI A: Extragastric manifestations of Helicobacter pylori infection. Helicobacter 17 (Suppl 1): 49-55, 2012.

BERGMAN MP, VANDENBROUCKE-GRAULS CM, APPELMELK BJ, D'ELIOS MM, AMEDEI A, AZZURRI A, BENAGIANO M, DEL PRETE G: The story so far: Helicobacter pylori and gastric autoimmunity. Int Rev Immunol 24: 63-91, 2005.

BERTALOT G, MONTRESOR G, TAMPIERI M, SPASIANO A, PEDRONI M, MILANESI B, FAVRET M, MANCA N, NEGRINI R: Decrease in thyroid autoantibodies after eradication of Helicobacter pylori infection. Clin Endocrinol (Oxf) 61: 650-652, 2004. 
BIRKHOLZ S, KNIPP U, OPFERKUCH W: Stimulatory effects of Helicobacter pylori on human peripheral blood mononuclear cells of H. pylori infected patients and healthy blood donors. Zentralbl Bakteriol 280: 166-176, 1993.

BLANCHARD TG, DRAKES ML, CZINN SJ: Helicobacter infection: pathogenesis. Curr Opin Gastroenterol 20: 10-15, 2004.

BLASER MJ, ATHERTON JC: Helicobacter pylori persistence: biology and disease. J Clin Invest 113: 321-333, 2004.

BLISS CM JR, GOLENBOCK DT, KEATES S, LINEVSKY JK, KELLY CP: Helicobacter pylori lipopolysaccharide binds to CD14 and stimulates release of interleukin-8, epithelial neutrophil-activating peptide 78, and monocyte chemotactic protein 1 by human monocytes. Infect Immun 66: 5357-5363, 1998.

BONCRISTIANO M, PACCANI SR, BARONE S, ULIVIERI C, PATRUSSI L, ILVER D, AMEDEI A, D'ELIOS MM, TELFORD JL, BALDARI CT: The Helicobacter pylori vacuolating toxin inhibits $\mathrm{T}$ cell activation by two independent mechanisms. $J$ Exp Med 198: 1887-1897, 2003.

CHMIELA M, LELWALA-GURUGE JA, WADSTROM T, RUDNICKA W: The stimulation and inhibition of T cell proliferation by Helicobacter pylori components. J Physiol Pharmacol 47: 195-202, 1996a.

CHMIELA M, PAZIAK-DOMANSKA B, LJUNGH A, WADSTROM T, RUDNICKA W: The proliferation of human T lymphocytes stimulated by Helicobacter pylori antigens. Immunobiology 195: 199-208, $1996 \mathrm{~b}$.

COVACCI A, TELFORD JL, DEL GIUDICE G, PARSONNET J, RAPPUOLI R: Helicobacter pylori virulence and genetic geography. Science 284: 1328-1333, 1999.

CRABTREE JE, FARMERY SM, LINDLEY IJ, FIGURA N, PEICHL P, TOMPKINS DS: CagA/cytotoxic strains of Helicobacter pylori and interleukin-8 in gastric epithelial cell lines. J ClinPathol 47: 945-950, 1994.

D'ELIOS MM, APPELMELK BJ, AMEDEI A, BERGMAN MP, DEL PRETE G: Gastric autoimmunity: the role of Helicobacter pylori and molecular mimicry. Trends Mol Med 10: 316-323, 2004.

DAS S, SUAREZ G, BESWICK EJ, SIERRA JC, GRAHAM DY, REYES VE: Expression of B7-H1 on gastric epithelial cells: its potential role in regulating $\mathrm{T}$ cells during Helicobacter pylori infection. $J$ Immunol 176: 3000-3009, 2006.

DE KOSTER E, DE BRUYNE I, LANGLET P, DELTENRE M: Evidence based medicine and extradigestive manifestations of Helicobacter pylori. Acta Gastroenterol Belg 63: 388-392, 2000.

De LUIS DA, VARELA C, De la CALlE H, CANTON R, DE ARGILA CM, SAN ROMAN AL, BOIXEDA D: Helicobacter pylori infection is markedly increased in patients with autoimmune atrophic thyroiditis. $J$ Clin Gastroenterol 26: 259-263, 1998.

Di BONAVENTURA G, CATAMO G, NERI M, NERI G, PICCOLOMINI R: Absence of Helicobacter pylori in tonsillar swabs from dyspeptic patients. New Microbiol 23: 445-448, 2000.

Di BONAVENTURA G, NERI M, NERI G, CATAMO G, PICCOLOMINI R: Do tonsils represent an extragastric reservoir for Helicobacter pylori infection. J Infect 42: 221-222, 2001.

DIBAISE JK, OLUSOLA BF, HUERTER JV, QUIGLEY EM: Role of GERD in chronic resistant sinusitis: a prospective, open label, pilot trial. Am J Gastroenterol 97: 843-850, 2002.

DINIS PB, MARTINS ML, SUBTIL J: Does Helicobacter pylori play a role in upper respiratory tract inflammation? A case report. Ear Nose Throat $J$ 84: 238-240, 2005.

FAN XJ, CHUA A, SHAHI CN, MCDEVITT J, KEELING PW, KELLEHER D: Gastric T lymphocyte responses to Helicobacter pylori in patients with H pylori colonisation. Gut 35: 1379-1384, 1994.

FIGURA N, DI CAIRANO G, LORE F, GUARINO E, GRAGNOLI A, CATALDO D, GIANNACE R, VAIRA D, BIANCIARDI L, KRISTODHULLU S, LENZI C, TORRICELLI V, ORLANDINI G, GENNARI C: The infection by Helicobacter pylori strains expressing CagA is highly prevalent in women with autoimmune thyroid disorders. $J$ Physiol Pharmacol 50: 817-826, 1999.

FIGURA N, FRANCESCHI F, SANTUCCI A, BERNARDINI G, GASBARRINI G, GASBARRINI A: Extragastric manifestations of Helicobacter pylori infection. Helicobacter 15 (Suppl 1): 60-68, 2010.

GEBERT B, FISCHER W, HAAS R: The Helicobacter pylori vacuolating cytotoxin: from cellular vacuolation to immunosuppressive activities. Rev Physiol Biochem Pharmacol 152: 205-220, 2004.

GEWIRTZ AT, YU Y, KRISHNA US, ISRAEL DA, LYONS SL, PEEK RM JR: Helicobacter pylori flagellin evades toll-like receptor 5-mediated innate immunity. J Infect Dis 189: 1914-1920, 2004. 
HAFSI N, VOLAND P, SCHWENDY S, RAD R, REINDL W, GERHARD M, PRINZ C: Human dendritic cells respond to Helicobacter pylori, promoting NK cell and Th1-effector responses in vitro. J Immunol 173: 1249$1257,2004$.

HASNI SA: Role of Helicobacter pylori infection in autoimmune diseases. Curr Opin Rheumatol 24: 429-434, 2012.

HATAKEYAMA M: Helicobacter pylori and gastric carcinogenesis. J Gastroenterol 44: 239-248, 2009.

HATAKEYAMA M, BRZOZOWSKI T: Pathogenesis of Helicobacter pylori infection. Helicobacter 11 (Suppl 1): 14-20, 2006.

HUSSEY DJ, WOODS CM, HARRIS PK, THOMAS AC, OOI EH, CARNEY AS: Absence of Helicobacter pylori in pediatric adenoid hyperplasia. Arch Otolaryngol Head Neck Surg 137: 998-1004, 2011.

HYBENOVA M, HRDA P, POTUZNIKOVA B, PAVLIK E, STEJSKAL V, DOSEDEL J, STERZL I: Lymphocyte proliferative response to Helicobacter pylori antigens in H. pylori-infected patients. Folia Microbiol 55: 649-656, 2010a.

HYBENOVA M, HRDA P, PROCHAZKOVA J, STEJSKAL V, STERZL I: The role of environmental factors in autoimmune thyroiditis. Neuro Endocrinol Lett 31: 283-289, 2010b.

JAKOB B, BIRKHOLZ S, SCHNEIDER T, DUCHMANN R, ZEITZ M, STALLMACH A: Immune response to autologous and heterologous Helicobacter pylori antigens in humans. Microsc Res Tech 53: 419-424, 2001.

KANDULSKI A, WEX T, KUESTER D, PEITZ U, GEBERT I, ROESSNER A, MALFERTHEINER P: Naturally occurring regulatory $\mathrm{T}$ cells $(\mathrm{CD} 4+, \mathrm{CD} 25$ high, FOXP3+) in the antrum and cardia are associated with higher H. pylori colonization and increased gene expression of TGF-beta1. Helicobacter 13: 295-303, 2008.

KARTTUNEN R: Blood lymphocyte proliferation, cytokine secretion and appearance of T cells with activation surface markers in cultures with Helicobacter pylori. Comparison of the responses of subjects with and without antibodies to H. pylori. Clin Exp Immunol 83: 396-400, 1991.

KATRA R, KABELKA Z, JUROVCIK M, HRADSKY O, KRAUS J, PAVLIK E, NARTOVA E, LUKES P, ASTL J: Pilot study: Association between Helicobacter pylori in adenoid hyperplasia and reflux episodes detected by multiple intraluminal impedance in children. Int J Pediatr Otorhinolaryngol 78: 1243-1249, 2014.

KAVIANI M KB, MOUSAVI SA, AZARPIRA N, ASHRAF MJ: Detection of helicobacter pylori in nasal polyps using rapid urease test and ELISA. Iran J Otorhinolaryngol 20: 189-196, 2009.

KIM HY, DHONG HJ, CHUNG SK, CHUNG KW, CHUNG YJ, JANG KT: Intranasal Helicobacter pylori colonization does not correlate with the severity of chronic rhinosinusitis. Otolaryngol Head Neck Surg 136: 390-395, 2007

KIZILAY A, SAYDAM L, AYDIN A, KALCIOGLU MT, OZTURAN O, AYDIN NE: Histopathologic examination for Helicobacter pylori as a possible etiopathogenic factor in laryngeal carcinoma. Chemotherapy 52: 80-82, 2006.

KNIPP U, BIRKHOLZ S, KAUP W, OPFERKUCH W: Immune suppressive effects of Helicobacter pylori on human peripheral blood mononuclear cells. Med Microbiol Immunol 182: 63-76, 1993.

KONTUREK PC, ERNST H, KONTUREK SJ, BOBRZYNSKI AJ, FALLER G, KLINGLER C, HAHN EG: Mucosal expression and luminal release of epidermal and transforming growth factors in patients with duodenal ulcer before and after eradication of Helicobacter pylori. Gut 40: 463-469, 1997.

KRAUS J, NARTOVA E, PAVLIK E, KATRA R, STERZL I, ASTL J: Prevalence of Helicobacter pylori in adenotonsillar hypertrophy in children. Acta Otolaryngol 134: 88-92, 2014.

LOGAN RP: Helicobacter pylori and gastric cancer. Lancet 344: 1078-1079, 1994

LUKES P, PAVLIK E, POTUZNIKOVA B, NARTOVA E, FOLTYNOVA E, PLZAK J, KATRA R, STERZL I, BARTUNKOVA J, BETKA J, ASTL J: Detection of Helicobacter pylori in oropharyngeal lymphatic tissue with real-time PCR and assessment of its carcinogenic potential. Eur Arch Otorhinolaryngol 271: 399-405, 2013.

LUNDGREN A, SURI-PAYER E, ENARSSON K, SVENNERHOLM AM, LUNDIN BS: Helicobacter pylori-specific CD4+ CD25high regulatory $\mathrm{T}$ cells suppress memory $\mathrm{T}$-cell responses to $\mathrm{H}$. pylori in infected individuals. Infect Immun 71: 1755-1762, 2003.

MALFERTHEINER MV, KANDULSKI A, SCHREIBER J, MALFERTHEINER P: Helicobacter pylori infection and the respiratory system: a systematic review of the literature. Digestion 84: 212-220, 2011. 
MALFITANO AM, CAHILL R, MITCHELL P, FRANKEL G, DOUGAN G, BIFULCO M, LOMBARDI G, LECHLER RI, BAMFORD KB: Helicobacter pylori has stimulatory effects on naive T cells. Helicobacter 11: 21-30, 2006.

MARTIN-DE-ARGILA C, BOIXEDA D, CANTON R, GISBERT JP, FUERTES A: High seroprevalence of Helicobacter pylori infection in coronary heart disease. Lancet 346: 310, 1995.

MOLINARI M, SALIO M, GALLI C, NORAIS N, RAPPUOLI R, LANZAVECCHIA A, MONTECUCCO C: Selective inhibition of Ii-dependent antigen presentation by Helicobacter pylori toxin VacA. J Exp Med 187: 135-140, 1998.

MORINAKA S, ICHIMIYA M, NAKAMURA H: Detection of Helicobacter pylori in nasal and maxillary sinus specimens from patients with chronic sinusitis. Laryngoscope 113: 1557-1563, 2003.

MUOTIALA A, HELANDER IM, PYHALA L, KOSUNEN TU, MORAN AP: Low biological activity of Helicobacter pylori lipopolysaccharide. Infect Immun 60: 1714-1716, 1992.

NARTOVA E, KRAUS J, PAVLIK E, LUKES P, KATRA R, PLZAK J, KOLAROVA L, STERZL I, BETKA J, ASTL J: Presence of different genotypes of Helicobacter pylori in patients with chronic tonsillitis and sleep apnoea syndrome. Eur Arch Otorhinolaryngol 271: 607-613, 2014.

NILSSON HO, PIETROIUSTI A, GABRIELLI M, ZOCCO MA, GASBARRINI G, GASBARRINI A: Helicobacter pylori and extragastric diseases - other Helicobacters. Helicobacter 10 (Suppl 1): 54-65, 2005.

NOMURA A, STEMMERMANN GN, CHYOU PH, KATO I, PEREZ-PEREZ GI, BLASER MJ: Helicobacter pylori infection and gastric carcinoma among Japanese Americans in Hawaii. N Engl J Med 325: 1132-1136, 1991.

NURGALIEVA ZZ, GRAHAM DY, DAHLSTROM KR, WEI Q, STURGIS EM: A pilot study of Helicobacter pylori infection and risk of laryngopharyngeal cancer. Head Neck 27: 22-27, 2005.

O'KEEFFE J, MORAN AP: Conventional, regulatory, and unconventional $\mathrm{T}$ cells in the immunologic response to Helicobacter pylori. Helicobacter 13: 1-19, 2008.

OZYURT M, GUNGOR A, ERGUNAY K, CEKIN E, ERKUL E, HAZNEDAROGLU T: Real-time PCR detection of Helicobacter pylori and virulence-associated cagA in nasal polyps and laryngeal disorders. Otolaryngol Head Neck Surg 141: 131-135, 2009.

PARSONNET J, FRIEDMAN GD, VANDERSTEEN DP, CHANG Y, VOGELMAN JH, ORENTREICH N, SIBLEY RK: Helicobacter pylori infection and the risk of gastric carcinoma. N Engl J Med 325: 1127-1131, 1991.

PARSONNET J, HANSEN S, RODRIGUEZ L, GELB AB, WARNKE RA, JELLUM E, ORENTREICH N, VOGELMAN JH, FRIEDMAN GD: Helicobacter pylori infection and gastric lymphoma. $N$ Engl J Med 330: 1267-1271, 1994.

PAVLIK E, LUKES P, POTUZNIKOVA B, ASTL J, HRDA P, SOUCEK A, MATUCHA P, DOSEDEL J, STERZL I: Helicobacter pylori isolated from patients with tonsillar cancer or tonsillitis chronica could be of different genotype compared to isolates from gastrointestinal tract. Folia Microbiol 52: 91-94, 2007.

PELLICANO R, FRANCESCHI F, SARACCO G, FAGOONEE S, ROCCARINA D, GASBARRINI A: Helicobacters and extragastric diseases. Helicobacter 14 (Suppl 1): 58-68, 2009.

PORTAL-CELHAY C, PEREZ-PEREZ GI: Immune responses to Helicobacter pylori colonization: mechanisms and clinical outcomes. ClinSci (Lond) 110: 305-314, 2006.

RADOSZ-KOMONIEWSKA H, BEK T, JOZWIAK J, MARTIROSIAN G: Pathogenicity of Helicobacter pylori infection. Clin Microbiol Infect 11: 602-610, 2005.

REALDI G, DORE MP, FASTAME L: Extradigestive manifestations of Helicobacter pylori infection: fact and fiction. Dig Dis Sci 44: 229-236, 1999.

REZAII J, TAVAKOLI H, ESFANDIARI K, ASHEGH H, HASIBI M, GHANEI G, KHOSH-BATN M, RASHIDI A: Association between Helicobacter pylori infection and laryngo-hypopharyngeal carcinoma: a case-control study and review of the literature. Head Neck 30: 1624-1627, 2008.

ROBINSON K, ARGENT RH, ATHERTON JC: The inflammatory and immune response to Helicobacter pylori infection. Best Pract Res Clin Gastroenterol 21: 237-259, 2007.

SACHS G, WEEKS DL, MELCHERS K, SCOTT DR: The gastric biology of Helicobacter pylori. Annu Rev Physiol 65: 349-369, 2003.

SALAMA NR, HARTUNG ML, MULLER A: Life in the human stomach: persistence strategies of the bacterial pathogen Helicobacter pylori. Nat Rev Microbiol 11: 385-399, 2013. 
SCHIEMANN U, KONTUREK J, ASSERT R, REMBIASZ K, DOMSCHKE W, KONTUREK S, PFEIFFER A: mRNA expression of EGF receptor ligands in atrophic gastritis before and after Helicobacter pylori eradication. Med Sci Monit 8: CR53-CR58, 2002.

SEZEN OS, KUBILAY U, ERZIN Y, TUNCER M, UNVER S: Does tonsillectomy affect the outcome of drug treatment for the eradication of gastric H pylori infection? A pilot study. Ear Nose Throat J 92: 127-132, 2013.

SKINNER LJ, WINTER DC, CURRAN AJ, BARNES C, KENNEDY S, MAGUIRE AJ, CHARLES DA, TIMON CI, BURNS HP: Helicobacter pylori and tonsillectomy. Clin Otolaryngol Allied Sci 26: 505-509, 2001.

SOLNICK JV, FRANCESCHI F, ROCCARINA D, GASBARRINI A: Extragastric manifestations of Helicobacter pylori infection - other Helicobacter species. Helicobacter 11 (Suppl 1): 46-51, 2006.

STERZL I, HRDA P, MATUCHA P, CEROVSKA J, ZAMRAZIL V: Anti-Helicobacter Pylori, anti-thyroid peroxidase, anti-thyroglobulin and anti-gastric parietal cells antibodies in Czech population. Physiol Res $\mathbf{5 7}$ (Suppl 1): S135-S141, 2008.

STROMBERG E, EDEBO A, SVENNERHOLM AM, LINDHOLM C: Decreased epithelial cytokine responses in the duodenal mucosa of Helicobacter pylori-infected duodenal ulcer patients. Clin Diagn Lab Immunol 10: 116-124, 2003.

SUAREZ G, REYES VE, BESWICK EJ: Immune response to H. pylori. World J Gastroenterol 12: 5593-5598, 2006.

SUNDRUD MS, TORRES VJ, UNUTMAZ D, COVER TL: Inhibition of primary human T cell proliferation by Helicobacter pylori vacuolating toxin (VacA) is independent of VacA effects on IL-2 secretion. Proc Natl Acad Sci U S A 101: 7727-7732, 2004.

TSANG KW, LAM SK: Helicobacter pylori and extra-digestive diseases. J Gastroenterol Hepatol 14: 844-850, 1999.

TUMMALA S, KEATES S, KELLY CP: Update on the immunologic basis of Helicobacter pylori gastritis. Curr Opin Gastroenterol 20: 592-597, 2004.

UNAL S, KARAKAN T, DOGAN I, CINDORUK M, DUMLU S: The influence of Helicobacter pylori infection on the prevalence of endoscopic erosive esophagitis. Helicobacter 11: 556-561, 2006.

UYUB AM, ANUAR AK: Inhibition of lymphocyte proliferative responses to Helicobacter pylori by plastic adherent cells. Southeast Asian J Trop Med Public Health 32: 88-94, 2001.

VAN DOORN LJ: Detection of Helicobacter pylori virulence-associated genes. Expert Rev Mol Diagn 1: 290-298, 2001.

VELIN D, MICHETTI P: Immunology of Helicobacter pylori infection. Digestion 73: 116-123, 2006.

VIALA J, CHAPUT C, BONECA IG, CARDONA A, GIRARDIN SE, MORAN AP, ATHMAN R, MEMET S, HUERRE MR, COYLE AJ, DISTEFANO PS, SANSONETTI PJ, LABIGNE A, BERTIN J, PHILPOTT DJ, FERRERO RL: Nod1 responds to peptidoglycan delivered by the Helicobacter pylori cag pathogenicity island. Nat Immunol 5: 1166-1174, 2004.

WANG Q, YU C, SUN Y: The association between asthma and Helicobacter pylori: a meta-analysis. Helicobacter 18: 41-53, 2013.

WIBAWA T, SURONO A, WIDODO I: Isolation of viable Helicobacter pylori in the tonsillar tissues of chronic tonsillitis patients. J Infect Dev Ctries 5: 561-564, 2011.

WINDLE HJ, ANG YS, ATHIE-MORALES V, MCMANUS R, KELLEHER D: Human peripheral and gastric lymphocyte responses to Helicobacter pylori NapA and AphC differ in infected and uninfected individuals. Gut 54: 25-32, 2005.

YANAOKA K, OKA M, OHATA H, YOSHIMURA N, DEGUCHI H, MUKOUBAYASHI C, ENOMOTO S, INOUE I, IGUCHI M, MAEKITA T, UEDA K, UTSUNOMIYA H, TAMAI H, FUJISHIRO M, IWANE M, TAKESHITA T, MOHARA O, ICHINOSE M: Eradication of Helicobacter pylori prevents cancer development in subjects with mild gastric atrophy identified by serum pepsinogen levels. Int $J$ Cancer $\mathbf{1 2 5}$ : 2697-2703, 2009.

YE XW, XIAO J, QIU T, TANG YJ, FENG YL, WANG K, OU XM: Helicobacter pylori seroprevalence in patients with obstructive sleep apnea syndrome among a Chinese population. Saudi Med J 30: 693-697, 2009. 